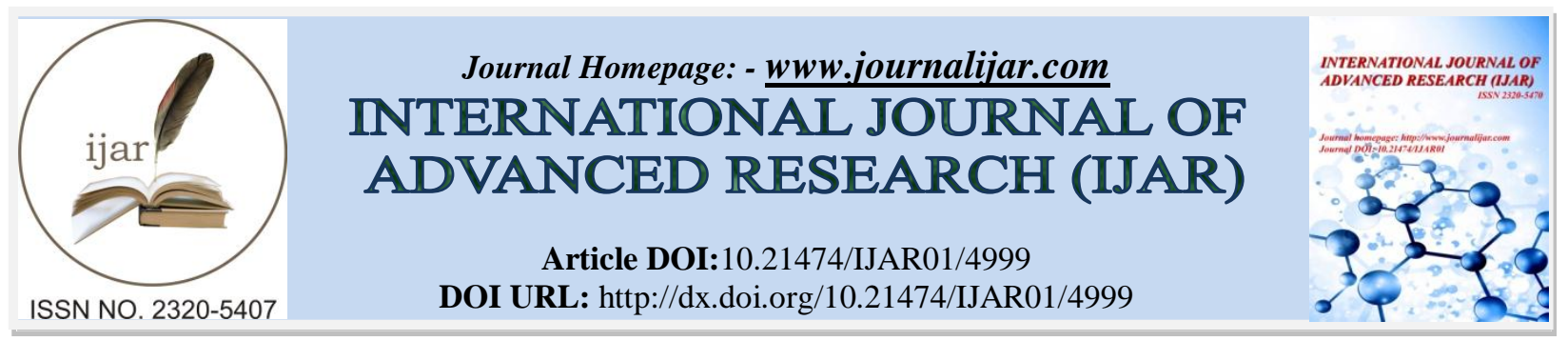

RESEARCH ARTICLE

\title{
EFFICACY OF INERT MATERIALS AGAINST RICE WEEVIL, SITOPHILUS ORYZAE (COLEOPTERA; CURCULIONIDAE) IN MILLED RICE GRAINS.
}

Gayatree Sahoo and Braja Kishore Sahoo.

Department of Entomology, Orissa University of Agriculture and Technology, Bhubaneswar, Odisha, India.

\section{Manuscript Info}

Manuscript History

Received: 28 May 2017

Final Accepted: 30 June 2017

Published: July 2017

Key words:-

Efficacy,Inert materials, Rice weevil, Milled rice grain.

\section{Abstract}

An experiment was carried out to study the efficacy of inert materials against rice weevil, Sitophilus oryzae in milled rice grains during 2015-16 in the Dept of Entomology, OUAT, Bhubaneswar in a Completely Randomized Design (CRD) with three replications. Results indicated that the lowest population build up, grain damage and grain weight loss of 17.33 nos, $5.12 \%$ and $4.92 \%$ respectively by S. oryzae was recorded with diatomaceous earth @0.5\% treatment at 150 days after treatment over the other treatments and was reported to have $93.27 \%$ inhibition rate of the $S$. oryzae population, $91.25 \%$ reduction in grain damage and $87.74 \%$ reduction in grain weight loss which was followed by camphor@0.5\%, boric acid@0.5\%, sodium bicarbonate @ $0.5 \%$ and salt @0.5\% treatment. Similarly at 150 days after treatment the lowest increase in grain moisture content up to $13.1 \%$ was reported in the diatomaceous earth treatment over the initial moisture content of $11.5 \%$.

Copy Right, IJAR, 2017,. All rights reserved.

\section{Introduction:-}

Grain storage is a serious problem confronted by every farmer and householder in developing countries like India by the insect pest attack where a considerable quantity of food grain is lost every year. Stored products of agricultural and animal origin are attacked by more than 600 species of beetles, 70 species of moths and 355 species of mites causing quantitative and qualitative loss. Among the several insects attacking stored grains, Sitophilus oryzae L. (Coleoptera: Curculionidae) is the most destructive insect pest of the stored raw cereal grains in the world (Champ and Dyte, 1976). Itcauses substantial losses to stored grain amounting 18.30 per cent (Adams, 1976). The use of inert dust to control stored grain pests is a technique with a long history and has been reviewed by many authors (Aldryhim, 1990). The inert dusts already exist in nature but are usually over looked by the households. Besides being very safe and presenting low toxicity in mammals, the inert dust does not affect the grain quality (Ebeling, 1971; Aldryhim, 1990). The main advantages of using inert materials are easy production by farmers, less expensive, biodegradable, broad spectrum, safe to apply, unique in action and are non-hazardous and non-toxic to human. In India few scientific research works have been done to explore locally available inert material for the management of harmful insect pest in storage by the farmers. So the present study was undertaken to study the bio efficacy of certain inert materials against rice weevil in milled rice grains. 


\section{Materials and methods:-}

The OUAT released "Jyotirmayee" variety of rice was selected for the experiment. The treated grains were prepared by mixing the specified dose of inert materials to $1 \mathrm{~kg}$ of milled rice grains and it was kept as such in a flask for 24 hours. Then the treated grains were ready for the experiment. The experiment was carried out at room temperature $29.23 \pm 1.67^{\circ} \mathrm{C}$ and RH $59.1 \pm 2.32 \%$.

The screening of the inert materials was carried out during December-2015 to April-2016 with treated milled rice grains in a completely randomized design (CRD) with three replications along with one untreated check. The moisture content of the grains were standardised at 11.5 percent level. Fifty grams of milled rice were taken in $150 \mathrm{gm}$ capacity plastic jars and then five pairs of newly emerged adults of Sitophilus oryzae L. were released. The mouths of the jars were closed with muslin cloth and tightened with the help of rubber band.

Observations were taken on population build-up of the Sitophilus oryzae L., grain damage (\%), grain weight loss $(\%)$, inhibition rate, reduction in grain damage and grain weight loss (\%) at 30 days interval up to 150 days after release and the increase in moisture content was recorded at the end of the screening process by using Digital moisture meter.

Inhibition rate $(\%)=\left[\left(C_{n}-T_{n}\right) / C_{n}\right] X 100$

Where $\mathrm{C}_{\mathrm{n}}=$ No. of insects in the control container

$\mathrm{T}_{\mathrm{n}}=$ No. of insects in the treatment container

\section{Result:-}

\section{Effect on population build up:-}

The population build-up of S.oryzae in the treatments with seven inorganic inert materials with an untreated check have been presented in Table 1. At 30 DAT in different treatments the adult $S$. oryzae population increased and were between 10.00 to 25.33 per $50 \mathrm{gm}$ of milled rice samples and in untreated check the initial population was increased from 10.00 to 33.67. In the treatment of diatomaceous earth @0.5\% no increase in the population was observed. But the treatment with sand @ $0.5 \%$ the population reached at 25.33 no. per 50 gm sample.

At 60 DAT minimum a population of 11.33 was observed in diatomaceous earth @0.5\% treatment followed by camphor, boric acid, sodium bicarbonate and salt all @ $0.5 \%$ with 15.00, 18.00, 24.00 and 26.33 nos. per 50 gm of sample respectively. A highest population was observed with sand @0.05\% with a adult weevil population of 38.00 as compared to untreated check (77.33). The same trend was also observed at 90 and 120 DAT.

Similarly 150 DAT the lowest $S$. oryzae population build up of 17.33 was observed in the treatment with diatomaceous earth followed by camphor (29.67), boric acid (37.33), sodium bicarbonate (42.33) and salt (45.33) respectively over the untreated check of 257.67. a highest population was observed in the sand treatment with 102.33 no.s of adult weevil per $50 \mathrm{gm}$ of milled rice grains.

The highest inhibition rate (IR) of the adult $S$. oryzae population was recorded with the diatomaceous earth treatment of $93.27 \%$ followed by camphor $(88.49 \%)$, boric acid $(85.51 \%)$, sodium bicarbonate $(83.57 \%)$ and salt $(82.41 \%)$ over the untreated check. The lowest IR was recorded in ash and sand treatment with 77.62 and $60.29 \%$ respectively.

\section{Effect on grain damage (\%) and Grain weight loss (\%):-}

At 30 DAT lowest grain damage and grain weight loss of only 1.12 and $1.31 \%$ was observed in the diatomaceous earth @ $0.5 \%$ treatment respectively. It was followed by camphor (1.51\% grain damage and $1.83 \%$ grain weight loss) and boric acid (3.11\% grain damage and $1.34 \%$ grain weight loss) as compared to the untreated check (18.19\% grain damage and $15.19 \%$ grain weight loss). Similar trend was also observed at 60, 90 and 120 DAT. At 150 DAT in the diatomaceous earth @ $0.5 \%$ treatment the lowest grain damage and grain weight loss of 5.12 and $4.92 \%$ was observed respectively. The next best treatment was camphor with grain damage of $7.72 \%$ and grain weight loss of $5.33 \%$ as compared to the untreated check of 58.49 and $40.12 \%$ grain damage and grain weight loss respectively. (Table 1) 
The reduction over grain damage and grain weight loss over the untreated check was observed in the diatomaceous earth treatment with 91.25 and $87.74 \%$ respectively which was followed by camphor ( 80.60 and $86.71 \%$ ), boric acid (85.31 and $81.68 \%)$, sodium bicarbonate $(82.00$ and $78.79 \%)$ and salt $(78.90$ and $67.90 \%)$ respectively. The lowest IR was recorded in sand treatment with 70.58 and $57.85 \%$ grain damage and grain weight loss respectively.

At the end of screening process i.e. at 150 DAT an increase in the grain moisture content was recorded in every treatments and it has been recorded and presented in Table 2. The final grain moisture content was recorded between 13.1 to $14.1 \%$ and $16.5 \%$ in the untreated check. The lowest moisture content of $13.1 \%$ was reported in the diatomaceous earth treatment followed by camphor (12.9\%), boric acid (13.1\%) and sodium bicarbonate (13.4\%) whereas the highest in sand with the grain moisture content of $14.1 \%$.

Table 1:-Screening test on the efficacy of inorganic inert materials against $S$. oryzae in milled rice grains.

\begin{tabular}{|c|c|c|c|c|c|c|c|c|c|c|c|c|c|c|c|c|c|c|}
\hline \multirow{2}{*}{$\begin{array}{c}\text { Treatm } \\
\text { ents }\end{array}$} & \multicolumn{6}{|c|}{ Population of S. oryzae } & \multicolumn{6}{|c|}{ Grain damage (\%) } & \multicolumn{6}{|c|}{ Grain wt loss (\%) } \\
\hline & $\begin{array}{c}\text { 30 } \\
\text { DAT }\end{array}$ & \begin{tabular}{|c|}
60 \\
DAT
\end{tabular} & $\begin{array}{c}90 \\
\text { DAT }\end{array}$ & $\begin{array}{c}120 \\
\text { DAT }\end{array}$ & $\begin{array}{c}150 \\
\text { DAT }\end{array}$ & \begin{tabular}{|c|} 
Redn. \\
over \\
UC \\
$(\%)$ \\
\end{tabular} & $\begin{array}{c}\text { 30 } \\
\text { DAT }\end{array}$ & $\begin{array}{c}\text { 60 } \\
\text { DAT }\end{array}$ & $\begin{array}{c}90 \\
\text { DAT }\end{array}$ & $\begin{array}{c}120 \\
\text { DAT }\end{array}$ & $\begin{array}{r}150 \\
\text { DAT }\end{array}$ & \begin{tabular}{|c|} 
Redn. \\
over \\
UC \\
$(\%)$
\end{tabular} & $\begin{array}{c}\text { 30 } \\
\text { DAT }\end{array}$ & \begin{tabular}{|c|}
60 \\
DAT
\end{tabular} & $\begin{array}{r}90 \\
\text { DAT }\end{array}$ & $\begin{array}{c}\text { 120 } \\
\text { DAT }\end{array}$ & $\begin{array}{r}150 \\
\text { DAT }\end{array}$ & $\begin{array}{c}\text { Redn. } \\
\text { over } \\
\text { UC } \\
(\%)\end{array}$ \\
\hline $\begin{array}{l}\text { T1 } \\
\text { (Campho } \\
\text { r) @ 0.5\% }\end{array}$ & $\begin{array}{c}12.67 \\
(3.62) \\
*\end{array}$ & $\begin{array}{c}15.00 \\
(3.94) \\
*\end{array}$ & $\begin{array}{c}20.67 \\
(4.60) \\
*\end{array}$ & $\begin{array}{c}27.33 \\
(5.27) \\
*\end{array}$ & $\begin{array}{c}29.67 \\
(5.49) \\
*\end{array}$ & 88.49 & $\begin{array}{c}1.51 \\
(6.67) \\
* *\end{array}$ & \begin{tabular}{|l}
3.18 \\
$(10.19)$ \\
$* *$
\end{tabular} & \begin{tabular}{|c|}
4.32 \\
$11.95)$ \\
$* *$
\end{tabular} & \begin{tabular}{|c}
6.41 \\
$(14.63)$ \\
$* *$
\end{tabular} & $\begin{array}{c}7.72 \\
(16.11) \\
*\end{array}$ & 86.80 & $\begin{array}{c}1.83 \\
(7.62) \\
* *\end{array}$ & $\begin{array}{c}2.91 \\
(9.67) \\
* *\end{array}$ & $\begin{array}{c}3.12 \\
(10.13 \\
* *\end{array}$ & $\begin{array}{c}4.23 \\
(11.67) \\
* *\end{array}$ & \begin{tabular}{|}
5.33 \\
$(13.11$ \\
$* *$
\end{tabular} & 86.71 \\
\hline $\begin{array}{l}\text { T2 (Salt) } \\
@ 0.5 \%\end{array}$ & $\begin{array}{l}14.00 \\
(3.81)\end{array}$ & \begin{tabular}{|l|}
26.33 \\
$(5.18)$
\end{tabular} & $\begin{array}{l}32.33 \\
(5.72)\end{array}$ & $\begin{array}{l}42.00 \\
(6.52)\end{array}$ & $\begin{array}{l}45.33 \\
(6.77)\end{array}$ & 82.41 & $\begin{array}{c}3.15 \\
(10.20)\end{array}$ & $\begin{array}{c}5.61 \\
(13.64)\end{array}$ & $\begin{array}{c}7.16 \\
(15.46)\end{array}$ & $\begin{array}{l}10.21 \\
18.58)\end{array}$ & $\begin{array}{c}12.34 \\
(20.56)\end{array}$ & 78.90 & $\left(\begin{array}{c}2.15 \\
(8.40)\end{array}\right.$ & $\begin{array}{c}5.69 \\
(13.77)\end{array}$ & $\begin{array}{c}8.81 \\
(17.26)\end{array}$ & $\begin{array}{c}9.26 \\
(17.58)\end{array}$ & $\begin{array}{c}12.88 \\
(20.94)\end{array}$ & 67.90 \\
\hline $\begin{array}{l}\mathrm{T} 3 \\
\text { (Sodium } \\
\text { bicarbona } \\
\text { ate) } \\
\text { @ } 0.5 \%\end{array}$ & $\begin{array}{r}13.67 \\
(3.76)\end{array}$ & \begin{tabular}{|l|}
24.00 \\
$(4.94)$
\end{tabular} & $\begin{array}{l}30.00 \\
(5.52)\end{array}$ & $\begin{array}{l}39.00 \\
(6.28)\end{array}$ & \begin{tabular}{|l|}
42.33 \\
$(6.54)$
\end{tabular} & 83.57 & \begin{tabular}{|l}
2.57 \\
$(9.20)$
\end{tabular} & $\begin{array}{c}4.32 \\
(11.93)\end{array}$ & $\begin{array}{c}6.58 \\
(14.83)\end{array}$ & $\begin{array}{c}9.31 \\
(17.65)\end{array}$ & $\begin{array}{c}10.53 \\
(18.90)\end{array}$ & 82.00 & $\begin{array}{l}1.92 \\
(7.93)\end{array}$ & $\begin{array}{c}3.18 \\
(10.24)\end{array}$ & $\begin{array}{c}4.29 \\
(11.87\end{array}$ & $\begin{array}{c}6.82 \\
(15.05)\end{array}$ & $\begin{array}{c}8.51 \\
(16.90)\end{array}$ & 78.79 \\
\hline \begin{tabular}{|l|}
$\mathrm{T} 4$ \\
(Diatoma \\
-eous \\
earth) \\
$@ 0.5 \%$
\end{tabular} & \begin{tabular}{|l|}
10.00 \\
$(3.24)$
\end{tabular} & \begin{tabular}{|l|}
11.33 \\
$(3.44)$
\end{tabular} & $\begin{array}{l}13.67 \\
(3.76)\end{array}$ & \begin{tabular}{|l}
14.67 \\
$(3.89)$
\end{tabular} & \begin{tabular}{|l|}
17.33 \\
$(4.22)$
\end{tabular} & 93.27 & \begin{tabular}{|c|}
1.12 \\
$(6.07)$
\end{tabular} & \begin{tabular}{|c}
1.98 \\
$(7.51)$
\end{tabular} & \begin{tabular}{|c|}
2.13 \\
$(8.28)$
\end{tabular} & \begin{tabular}{|l|}
4.63 \\
$12.37)$
\end{tabular} & $\begin{array}{c}5.12 \\
(12.97)\end{array}$ & 91.25 & $\begin{array}{c}1.31 \\
(6.52)\end{array}$ & $\begin{array}{c}2.15 \\
(8.20)\end{array}$ & $\begin{array}{r}3.11 \\
(9.82)\end{array}$ & \begin{tabular}{|c}
3.74 \\
$(11.06)$
\end{tabular} & \begin{tabular}{|c|}
4.92 \\
$(12.79)$
\end{tabular} & 774 \\
\hline $\begin{array}{l}\text { T5 (Ash) } \\
@ 0.5 \%\end{array}$ & $\begin{array}{l}14.33 \\
(3.85)\end{array}$ & \begin{tabular}{|l|}
28.00 \\
$(5.33)$ \\
\end{tabular} & \begin{tabular}{|l|}
35.67 \\
$(6.00)$ \\
\end{tabular} & \begin{tabular}{|l|}
45.00 \\
$(6.74)$ \\
\end{tabular} & $\begin{array}{l}57.67 \\
(7.61)\end{array}$ & 77.62 & \begin{tabular}{|c|}
3.11 \\
$(10.04)$ \\
\end{tabular} & $\begin{array}{c}7.21 \\
(15.56 \\
\end{array}$ & $\begin{array}{l}10.01 \\
(18.42) \\
\end{array}$ & $\begin{array}{c}11.21 \\
(19.51)\end{array}$ & $\begin{array}{c}14.88 \\
(22.66) \\
\end{array}$ & 74.56 & $\begin{array}{c}3.02 \\
(9.86) \\
\end{array}$ & $\begin{array}{c}5.26 \\
(13.08) \\
\end{array}$ & $\begin{array}{c}9.78 \\
(18.22)\end{array}$ & \begin{tabular}{|l|}
10.71 \\
$(19.03)$
\end{tabular} & $\begin{array}{c}13.98 \\
(21.93) \\
\end{array}$ & 65.15 \\
\hline $\begin{array}{l}\text { T6 } \\
\text { (Sand) } \\
@ 0.5 \% \\
\end{array}$ & $\begin{array}{l}25.33 \\
(5.08)\end{array}$ & \begin{tabular}{|l|}
38.00 \\
$(6.20)$
\end{tabular} & \begin{tabular}{|l|}
58.00 \\
$(7.64)$
\end{tabular} & $\begin{array}{l}76.33 \\
(8.76)\end{array}$ & $\begin{array}{l}102.33 \\
(10.14)\end{array}$ & 60.29 & \begin{tabular}{|l|}
4.15 \\
$(11.68)$
\end{tabular} & $\begin{array}{c}9.58 \\
(17.87)\end{array}$ & \begin{tabular}{|c|}
12.19 \\
$(20.38)$
\end{tabular} & $\begin{array}{c}15.43 \\
(23.06)\end{array}$ & $\begin{array}{c}17.21 \\
(24.50)\end{array}$ & 70.58 & $\begin{array}{c}4.01 \\
(11.54)\end{array}$ & $\begin{array}{c}5.75 \\
(13.85)\end{array}$ & $\begin{array}{c}8.61 \\
(16.96)\end{array}$ & $\begin{array}{l}12.18 \\
(20.34)\end{array}$ & $\begin{array}{c}16.91 \\
(24.27)\end{array}$ & 57.85 \\
\hline $\begin{array}{l}\text { T7(Boric } \\
\text { acid) } \\
@ 0.5 \%\end{array}$ & c13.00 & \begin{tabular}{|l|}
18.00 \\
$(4.28)$
\end{tabular} & $\begin{array}{l}29.67 \\
(5.48)\end{array}$ & $\begin{array}{l}36.00 \\
(6.04)\end{array}$ & $\begin{array}{l}37.33 \\
(6.15)\end{array}$ & $\begin{array}{c}85 . \\
51\end{array}$ & $\begin{array}{c}3.11 \\
(10.00)\end{array}$ & $\begin{array}{c}5.12 \\
(13.02)\end{array}$ & $\begin{array}{c}8.86 \\
(17.12)\end{array}$ & $\begin{array}{c}7.33 \\
(15.57)\end{array}$ & $\begin{array}{c}8.59 \\
(17.03)\end{array}$ & $\begin{array}{r}85 . \\
31\end{array}$ & $\begin{array}{c}1.34 \\
(6.46)\end{array}$ & $\begin{array}{c}2.75 \\
(9.36)\end{array}$ & $\begin{array}{c}4.23 \\
(11.81)\end{array}$ & $\begin{array}{c}5.17 \\
(12.93)\end{array}$ & $\begin{array}{c}7.35 \\
(15.69)\end{array}$ & $\begin{array}{l}81 . \\
68\end{array}$ \\
\hline \begin{tabular}{|c|}
$\mathrm{T} 8$ \\
Untreated \\
check)
\end{tabular} & $\begin{array}{c}33.67 \\
(5.8 \\
4)\end{array}$ & $\begin{array}{l}77 . \\
33 \\
(8 . \\
82)\end{array}$ & $\begin{array}{c}153 . \\
33 \\
(12 . \\
40)\end{array}$ & $\begin{array}{c}188 . \\
67 \\
(13 . \\
75)\end{array}$ & $\begin{array}{c}257 . \\
67 \\
(16.0 \\
7)\end{array}$ & - & $\begin{array}{c}18.1 \\
9 \\
(25 . \\
23)\end{array}$ & $\begin{array}{c}27.6 \\
9 \\
(31 . \\
74)\end{array}$ & $\begin{array}{c}34.6 \\
5 \\
(36 . \\
06)\end{array}$ & $\begin{array}{c}45.4 \\
8 \\
(42 . \\
40)\end{array}$ & $\begin{array}{c}58.4 \\
9 \\
(49 . \\
90)\end{array}$ & - & $\begin{array}{c}15.1 \\
9 \\
(22 . \\
84)\end{array}$ & $\begin{array}{c}22.1 \\
8 \\
(28 . \\
00)\end{array}$ & $\begin{array}{c}29.3 \\
3 \\
(32 . \\
76)\end{array}$ & $\begin{array}{c}37.2 \\
8 \\
(37 . \\
59)\end{array}$ & $\begin{array}{c}40.1 \\
2 \\
(39 . \\
28)\end{array}$ & - \\
\hline SEm $( \pm)$ & 0.02 & 0.02 & 0.03 & 0.02 & 0.03 & - & 0.93 & 1.52 & 1.17 & 1.49 & 0.80 & - & 0.98 & 1.64 & 1.34 & 2.35 & 1.53 & - \\
\hline $\mathrm{CD}_{0.05}$ & 0.05 & 0.07 & 0.10 & 0.07 & 0.08 & - & 2.80 & 4.54 & 3.51 & 4.48 & 2.39 & - & 2.94 & 4.91 & 4.02 & 7.04 & 4.58 & - \\
\hline
\end{tabular}

DAT- Days After Treatment, * Figures in the parentheses are the square root $(\mathrm{x}+0.5)$ transformation values. **Figures in the parentheses are the angular transformation values,

Table 2:-Moisture content (\%) of milled rice grains at the end of screening process of inert materials

\begin{tabular}{|l|c|c|l|c|c|}
\hline \multicolumn{1}{|c|}{ Treatments } & $\begin{array}{c}\text { Initial MC } \\
(\mathbf{\%})\end{array}$ & $\begin{array}{c}\text { Final MC } \\
(\mathbf{\%})\end{array}$ & \multicolumn{1}{|c|}{ Treatments } & $\begin{array}{c}\text { Initial MC } \\
(\mathbf{\%})\end{array}$ & $\begin{array}{c}\text { Final MC } \\
(\mathbf{\%})\end{array}$ \\
\hline T1(Camphor) & 11.5 & 12.9 & T5 (Ash) & 11.5 & 13.6 \\
\hline T2 (Salt) & 11.5 & 13.8 & T6 (Sand) & 11.5 & 14.1 \\
\hline $\begin{array}{l}\text { T3 (Sodium } \\
\text { bicarbonate) }\end{array}$ & 11.5 & 13.4 & T7(Boric acid) & 11.5 & 13.1 \\
\hline $\begin{array}{l}\text { T4 (Diatomaceous } \\
\text { earth) }\end{array}$ & 11.5 & 12.7 & T8 (Untreated check) & 11.5 & 16.5 \\
\hline
\end{tabular}

MC - Moisture content 


\section{Discussion:-}

The population build up of the $S$. oryzae in the treatments with the inert materials along with the untreated check revealed that at 150 DAT the lowest $S$. oryzae population build up of 17.33 was observed in the treatment with diatomaceous earth followed by camphor (29.67), boric acid (37.33), sodium bicarbonate (42.33) and salt (45.33) respectively over the untreated check of 257.67. However Gupta and Saxena (2010) demonstrated the contact and fumigant toxicity of camphor against several stored products insects which justifies our findings. Besides Dayal et al. (2003) evaluated the efficacy of salt $(1.0 \mathrm{ml} / \mathrm{kg})$ as grain protectant against $S$. oryzae in Basmati rice and found significant decrease in weevil population and grain damage as compared to the untreated check which is in agreement of the recent results. A highest population was observed in the sand treatment with 102.33 nos. of adult weevil per $50 \mathrm{gm}$ of milled rice grains.

At 150 DAT in the diatomaceous earth @ $0.5 \%$ treatment the lowest grain damage and grain weight loss of 5.12 and $4.92 \%$ was observed respectively. The next best treatment was camphor with grain damage of $7.72 \%$ and grain weight loss of $5.33 \%$ as compared to the untreated check of 58.49 and $40.12 \%$ grain damage and grain weight loss respectively.

The highest inhibition rate (IR) of the adult $S$. oryzae population was recorded with the diatomaceous earth treatment of $93.27 \%$ (Table 1). This high rate of inhibition rate may be due to the mechanism that the small particles of this dust adhere to insect's body and remove the epicuticular wax, causing death by dehydration (Subramanyam \& Roesli, 2000). However Ceruti et al. (2008) reported that treatment of diatomaceous earth @ 750 and $1000 \mathrm{mg} / \mathrm{kg}$ caused highest mortality of Sitophillus zeamais in stored corn at 25 and $30^{\circ} \mathrm{C}$.

The reduction over grain damage and grain weight loss over the untreated check was observed in the diatomaceous earth treatment with 91.25 and $87.74 \%$ respectively which was followed by camphor $(80.60$ and $86.71 \%)$, boric acid (85.31 and $81.68 \%)$, sodium bicarbonate (82.00 and $78.79 \%)$ and salt $(78.90$ and $67.90 \%)$ respectively. Ahmed (2015) reported the advantage of using boric acid is that, it destroys the cellular lining of the foregut of insects which strengthens and proves the present finding that boric acid is the next best treatment after diatomaceous earth and camphor. Mulungu et al., (2010) reported that when sodium bicarbonate used @ 2\% (w/w), the grain weight loss by S. zeamais was only $50 \mathrm{~g} / 200 \mathrm{~g}$ sample maize grain over the control which is deviated from our reports.

According to Karthikeyan et al. (2006) ash treatment during storage was found effective for controlling the storage losses up to $80 \%$ which contradicts the present finding of reducing the grain weight loss up to $57.85 \%$ only.

At the end of screening process i.e. at 150 DAT an increase in the grain moisture content was recorded between 13.1 to $14.1 \%$ and $16.5 \%$ in the untreated check. The lowest moisture content of $13.1 \%$ was reported in the diatomaceous earth treatment whereas the highest in sand with the grain moisture content of $14.1 \%$. As per Delouche (1973) the seed moisture content is a function of ambient RH and the infestation, growth and reproduction of storage insects which competently supports the present findings.

\section{References:-}

1. Adams, J.M. (1976). Weight loss caused by development of S. oryzae.Journal of Stored Production Research. $12: 269-272$.

2. Ahmed, F.S. (2015). Toxicological studies on boric acid, Imidacloprid and fipronil and their binary Mixtures as insecticides on german cockroach Blattella germanica (L.) (Dictyoptera: Blattellidae). Thesis Submitted for the Degree of Master of Science in Agricultural Sciences (Pesticides) Department of Economic Entomology and Pesticides Faculty of Agriculture Cairo University Egypt.

3. Aldryhim, Y.N. (1990). Efficacy of the amorphous silica dust, Dryacide, against Tribolium confusum Duv. And Sitophilus granaries (L.) (Coleoptera: Tenebrionidae and Curculionidae). Journal of Stored Products Research. 26: 207-210.

4. Ceruti, F.C., Lazzari, S.M.N., Lazzarim, F.A. and Pinto Junior, A.R. (2008). Efficacy of Diatomaceous earth and temperature to control maize weevil in stored maize. Scientia Agraria. Curitiba. 9(1): 73-78.

5. Champ, B.R. and Dyte, C. (1976). Global survey of pesticide susceptibility of stored grain pests. FAO Plant Protection Science. No. 5, FAO, Rome

6. Dayal, R., Tripathi, R. A. and Renu. A. (2003). Comparative efficacy of some botanicals as protectant against S. oryzae in rice and its palatibility. Annals of Plant Protection Sciences. 11(1):160-162. 
7. Delouche, J.C., Matthes, R.K., Daugherty, G.M. and Boyd, A.H. (1973). Storage of seed in subtropical and tropical regions. Seed Science and Technology. 1: 671-700.

8. Ebeling, W. (1971). Sorptive dusts for pest control. Annual Review of Entomology, 16:122-158.

9. Gupta, N., Saxena, G. (2010). Identification and application of bioactive principles from Mentha, Annona, Cinnamomum and Eucalyptus against stored pulse grain pest. Asian Journal of Chemical Environtal Research.3:82-86.

10. Karthikeyan, C., Veerraragavathatham, D. and Firdouse, S.A. (2006). Cow based indigenous technologies in dryfarming. Indian Journal of Traditional Knowledge. 5: 104-107.

11. Mulungu, L.S., Kubala, T., Mhamphi, G.G., Misangu, R. and Mwatawala, M.W. (2010). Efficacy of protectants against Maize weevils (Sitophilus zeamais M.) and the larger grain borer (Prostphanus trucantus H.) for stored maize. International Journal of Plant Science. 1(6):150-154.

12. Subramanyam, B. and Roelsi, R. (2000). Inert dusts. In: Subramanyam, B., Hagstrum, D.W. (Eds.), Alternatives to pesticides in stored-product IPM, Kluwer Academic Publishers, Norwell, pp. 321-380. 